\title{
Water use efficiency of corn among the irrigation districts across the Duero river basin (Spain): Estimation of local crop coefficients by satellite images
}

\author{
Daniel Alberto Segovia-Cardozo, Leonor Rodríguez-Sinobas*, Sergio Zubelzu \\ Research Group "Hydraulics for Irrigation", Universidad Politécnica de Madrid, Escuela Técnica Superior de Ingeniería Agronómica, Alimentaria y de Biosistemas. Avda. \\ Puerta de Hierro 2, Ciudad Universitaria, 28040, Madrid, Spain
}

\section{A R T I C L E I N F O}

\section{Keywords:}

Water use efficiency

Crop water requirements

Crop coefficient

Irrigation requirements

Remote sensing

Satellite images

\begin{abstract}
A B S T R A C T
Irrigation in the Duero river basin accounts for $75 \%$ of total water resources. Nevertheless, irrigation in this area is paramount to maintain agricultural production. Within this context, this paper is aimed at assessing the water use efficiency (WUE), for the major crop (corn), among four irrigation districts (IDs) from 2014 to 2017. Since the WUE indicators base upon crop water requirements, these were calculated by estimating the reference evapotranspiration and the local crop coefficients Kc. First, they were estimated by satellite images and then, compared with the recommendation from the Regional Irrigation Advisory Service. Finally, the gross irrigation requirements were compared with the irrigation supply.

WUE indicators varied among IDs depending upon the hydrologic year, the water available for irrigation (superficial and subsurface water), and the corn sowing date. Usually, the IDs performed deficit irrigation in the dry years, and either full irrigation or over irrigation in the wet years. The rainfall only fulfilled less than $10 \%$ of corn requirements. Small differences in Kc were observed within municipalities (in each ID) and/or among IDs. The pattern of the Kc fitted curves varied among IDs and was affected by sowing dates.

Although, the local Kc values were close to the general coefficients recommended by the Irrigation Advisory Service, they affected the determination of gross irrigation requirements which were significant different among IDs. Moreover, it was observed that the FAO recommendation for the duration of the corn growth stages fitted better the estimated Kc than the one from the Advisory Center.

The gross irrigation requirements were similar among IDs and years, varying between 6476 and $7646 \mathrm{~m}^{3} / \mathrm{ha}$. The local Kc estimation could help irrigation managers to adapt the irrigation supply to the actual corn needs.
\end{abstract}

\section{Introduction}

According to FAO (2017), the earth`s population could reach 10 billion of habitants by 2050 which will boost agricultural demand for staple foods. In addition, the effect of climate change could affect food production worldwide. Irrigated agriculture provides higher crop yield than rain fed agriculture. However, its average water consumption is about $75 \%$ in a world where not only water is scarce but it is also foreseen the scarcity will continue in the future. Likewise at global scale, the crop yield for major crops such as maize, rice, and wheat are levelled off since 1990's. Within this context, the high water consumption in the agricultural sector highlights the need to adopt joint strategies aimed at achieving proper water use efficiency. Moreover, the sector would be affected by the reduction on water supply, and this might have a negative impact on the National gross income.

Water resources can be assessed at field scheme or regional scale by means of water use efficiency WUE indicators (Bos, 1997; Clemmens and Molden, 2007; Droogers and Kite, 1999; Droogers et al., 2000;

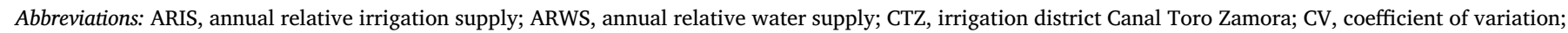

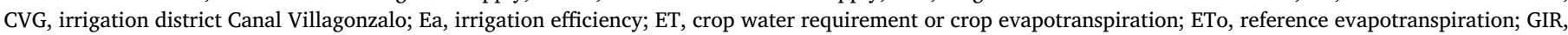

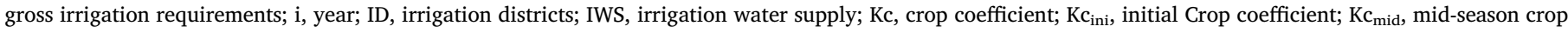

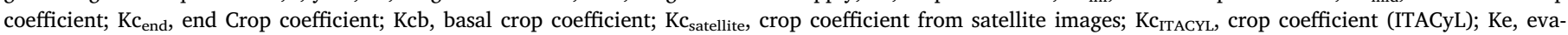

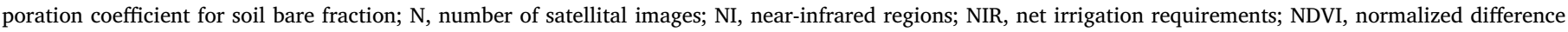

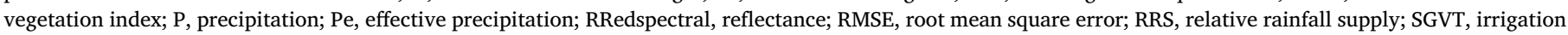

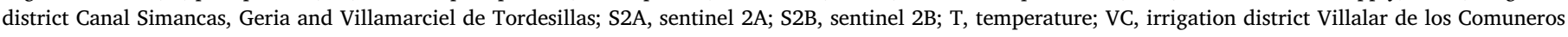
Sector I; WUE, water use efficiency

* Corresponding author.

E-mail address: leonor.rodriguez.sinobas@upm.es (L. Rodríguez-Sinobas).
} 
Kassam et al., 2007). They also have been applied to propose measures to increase water use efficiency (Vazifedoust et al., 2008).

In Spain, irrigated agriculture is performed within the irrigation district ID where agricultural producers are associated for the management of the irrigation system. The WUE indicators have been applied to assess the irrigation performance and suggest criteria for irrigation management. Lorite et al. (2004a, 2004b), Moreno-Pérez and Roldán-Cañas (2013) and, Andrés and Cuchí (2014) have characterized water use in several IDs in the Guadalquivir river basin, and showed the effect of crop, soil texture and irrigation method on irrigation management. Salvador et al. (2011), evaluated the irrigation performance, and its variability, between irrigation systems and crops in the Ebro river basin. Naroua et al. (2014) assess the irrigation strategy of farmer`s in the Adaja irrigation district (Castilla and León region).

Most of the studies cited above highlighted the benefits of a proper estimation of crop coefficient Kc to determine crop water requirements and thus, to ensure an adequate irrigation supply. Guerra et al. (2016) have presented several procedures to estimate Kc through different methodologies such us: soil water balance (Allen et al., 1998; Sun et al., 2006) or remote sensing and geographic information systems (Battude et al., 2017; Calera et al., 2004, 2017; Casa et al., 2009; Consoli and Barbagallo, 2012; Gontia and Tiwari, 2010; Melton et al., 2012; Pôças et al., 2015; Roerink et al., 1997; Zohrab Samani et al., 2009). Other studies (Marques et al., 2005; Lu et al., 2017) have shown the implication of the Kc estimation not only in the determination of irrigation supply but in optimizing water productivity.

The Kc estimation requires to measure crop-specific parameters such as leaf area index and albedo. Since their calculation is complex in local conditions, without specific instruments, their values frequently are selected from the FAO-56 table.

Nowadays, the remote sensing technology can estimate Kc from the multispectral images sent by sensors on board spacecraft, airborne or on land (Calera et al., 2004; Glenn et al., 2011).

In general, satellite-based ET, focusing on vegetation indices, or ground-based energy balance methods are time consuming, and require a learned skill sets (Allen et al., 2011). Although the last are simpler, both of them estimate Kc coefficients though the general vegetation indices which correspond to vegetation cover, leaf area, and transpiration (Glenn et al., 2008).

The Normalized Difference Vegetation Index (NDVI) is a common index estimated from two shortwave bands typically measured by satellites: the red band $(\sim 0.6-0.7 \mathrm{~m})$ and the near infrared band $(\sim 0.7-1.3 \mathrm{~m})$ (Allen et al., 2011).

The crop coefficient Kc can be estimated from the so-called dual crop coefficient as:

$\mathrm{Kc}=\mathrm{Kcb}+\mathrm{Ke}$

Where: Kcb is the basal crop coefficient, that refers to the transpiration of the plant (ratio between the crop transpiration without water stress and ETo), and Ke considers the evaporation from the bare soil fraction.

The lineal relation between Kcb and NDVI is accurate since it doesn't include soil evapotranspiration (Glenn et al., 2008; GonzalezDugo et al., 2009; Vanino et al., 2015). Bausch and Neale (1987) reported one of the first studies to set up a relationship between the reflected canopy radiation and NDVI. They calculated Kcb corn coefficients from NDVI in EEUU.

Tucker et al. (1979), monitored corn and soybean development with hand-held radiometer spectral data. Later, Bausch (1993) assessed the soil background effects on reflectance-based crop coefficients for corn and Neale et al. (1989) developed a reflectance based crop coefficients. The remote sensing techniques have improved faster and have been applied mainly to the estimation of crop coefficients in crops with high economic value such as vineyards (Vanino et al., 2015). A complete review of Remote Sensing for Crop Water Management in Mediterranean regions can be found in Calera et al. (2017).
In Spain, the Irrigation Advisory Services recommend Kc coefficients for corn in the irrigation districts across the country. In some regions, these coefficients came from FAO datasets (for initial stage $=$ 0.3 , for mid-season $=1.2$ and for end-season $=0.6-0.35$ ). In others such as in the Castilla La Mancha (Central Spain), they recommended:0.4, 1.15 and 0.6 for each stage, respectively. In the Andalucia region (South Spain), recommended 0.3, 1.15 and [0.6-0.35] for each stage, respectively and (Villalobos and Fereres, 2002). Likewise, Calera et al. (2004) monitored barley and corn growth, at field scale from remote sensing data in the Castilla La Mancha region, and Cuesta et al. (2005) proposed and validated a methodology to estimate the Kc in different herbaceous crops, including corn. Their results were compared with the recommendations given by the Irrigation advisory Services. Calera et al. (2017) have described the procedure to determine Kc coefficient in Spain trough the SPIDERWEBGIS open software, based on remote sensing, which has processed satellite image since 2014. However, in the Castilla and Leon region, the Kc coefficients are not yet been adapted to their local environment and there is a need for their estimation to determine a proper crop water requirements and irrigation supply. Hence, this work seeks to fill this gap and provide tools and suggestions for better irrigation and water application in the study area.

\section{Objectives}

The main objective of this study is the estimation and evaluation of the irrigation water use efficiency WUE of the major crop (corn) among the Spanish irrigation districts in the Duero river basin (Castilla and León region). It used the common water efficiency indicators but the crop needs are estimated by local Kc coefficients determined by satellite images considering different scales: field plots, municipality and irrigation district. Moreover, the spatial Kc variability among scales is assessed. Finally, the Kc coefficients are compared with the actual coefficients recommended by the Irrigation Advisory Services for Castilla and León (ITACyL), in order to advise local stakeholders to improve corn irrigation management in the region.

\section{Materials and methods}

\subsection{Description of the study area}

The study focuses on four irrigation districts IDs: Canal Simancas, Geria and Villamarciel of Tordesillas SGVT (616 ha of irrigation), Canal Toro Zamora CTZ (6962 ha of irrigation), Canal Villagonzalo CVG (4100 ha of irrigation) and Villalar of Comuneros VC (296 ha of irrigation). They locate across the basin of the Duero river basin (Castilla and León region) in the northwestern Spain as it is shown in Fig. 1.

According to the information of the last four years, corn (Zea mays L.) is one of the major crops cultivated in the IDs and is irrigated during the summer months to fulfil its high water requirements. The area devoted to this crop in each irrigation district is: SGVT 590 ha (95\%); CTZ, 2781 ha (40\%); CVG, 2413 ha (59\%) and VC, 15 ha (5\%). Sprinkler irrigation is used in the $31 \%$ and $47 \%$ of the area in CTZ and CVG, respectively but unfortunately the other two IDs did not bring this information.

The area has a continental Mediterranean climate with long and cold winters (average temperatures between 3 and $6{ }^{\circ} \mathrm{C}$ ), and short and hot summers (average temperature from 19 to $22^{\circ} \mathrm{C}$ ). Likewise, rainfall is scarce, about a $450-500 \mathrm{~mm} /$ year (average) more accentuated at the low lands areas (Nafría et al., 2013).

Regarding to the information published by ITACYL (2017), the most frequent soil textures at each irrigation district location are: SGVT loamy clay sand and loamy sand; CTZ loamy clay sand; CVG loamy sand, loam or sandy loam, and VC loamy clay sand or sandy loam.

Even though, the Duero river basin is the second largest in Spain, the climate variability, especially precipitation, exhibited in the last 


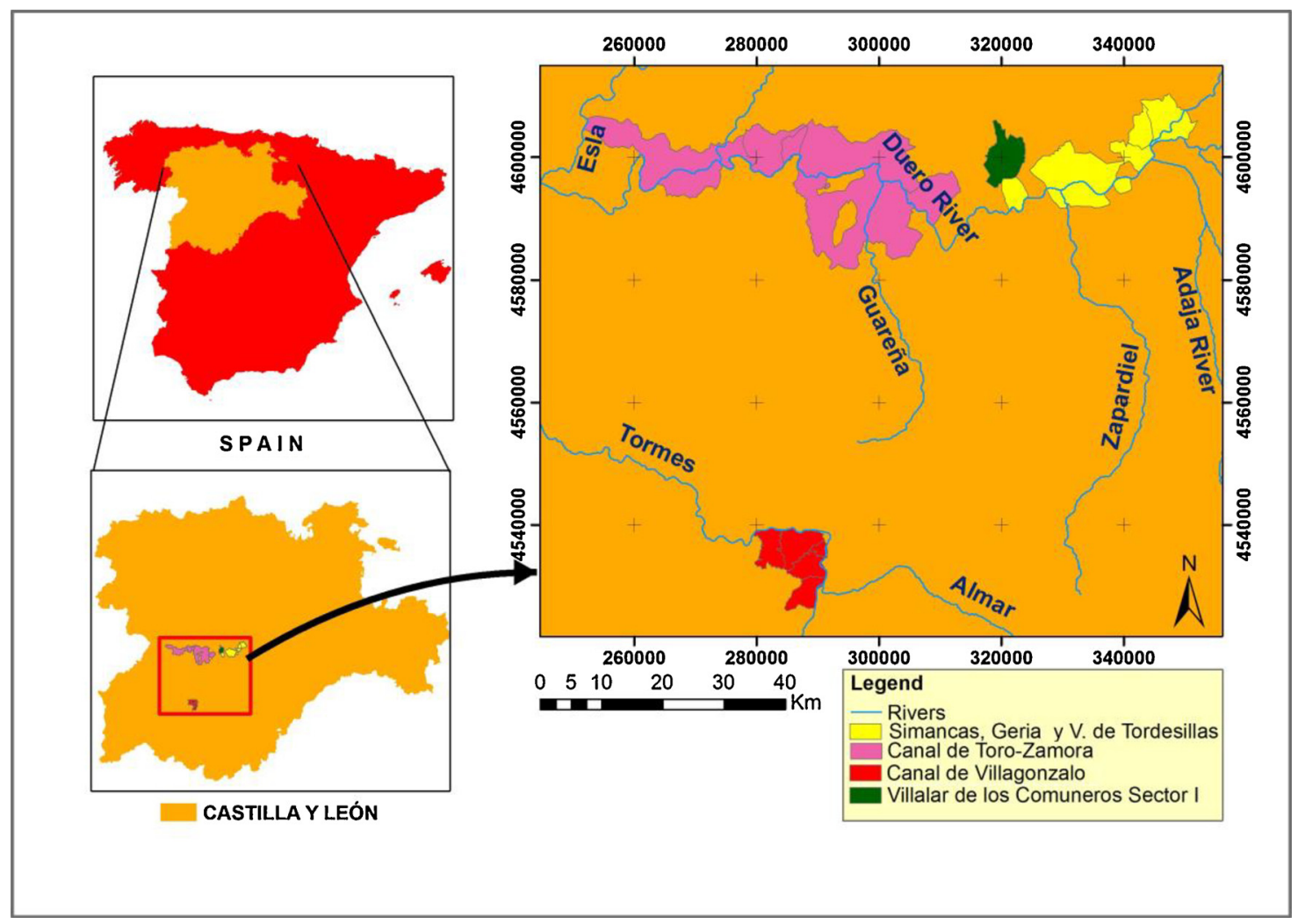

Fig. 1. Location of the irrigation districts in the Duero river basin.

decade has decreased the water availability for irrigation. At the beginning of the irrigation season, water storage in the reservoirs decreased from 30 to $50 \%$ below their full capacity during the last years, resulting in a permanent threat to farmers who cannot cultivate the whole irrigated surface maintaining the agroecosystems. Thus, local Kc estimation is needed to increase irrigation efficiency and decrease water losses.

The study considered 143 field plots, where corn was cultivated from 2014 to 2017, to study both temporal and spatial Kc variation. They covered 360 ha across 13 municipalities and four IDs as Table 1 depicts.

\subsection{Estimation of crop coefficients}

The Kc coefficients were estimated using the on-line platform SPIDERWEBGIS - SPIDER SIAR, which stored a historic data base of satellite images since 2014 that were used to estimate the NDVI index and from them the Kcb values. The data are available for download free of charge for Spain from http://maps.spiderwebgis.org/login/?custom= spider-siar. (Accessed January 2018). The satellite image come from the sensors of satellites Landsat8, Sentinel $2 \mathrm{~A}$ and $2 \mathrm{~B}$, which characteristics are presented in Table 2, all the three were used in this work

The NDVI is obtained from the multispectral images through an algebraic combination of the red and near infrared reflectivity. Campos et al. (2010) proposed the following relationship (Eq. (2)) that provides accurate results. This is the one used by SPIDER-SIAR to determine Kcb.

$K c b=1.44 * N D V I-0.1=\frac{1.44(N I-R)}{N I+R}-0.1$

In which $\mathrm{NI}$ is the light intensity of the near infrared regions and $\mathrm{R}$ is the light intensity of the red band.

Calera et al. (2005) and Cuesta et al. (2005) proposed the expression in Eq. (3) to determine Kc. In Spain, it was validated in Castilla La Mancha regions for crops such as: corn, wheat, cotton, barley and
Table 1

Information of the Irrigation Districts.

\begin{tabular}{|c|c|c|c|c|c|c|c|}
\hline \multirow{2}{*}{$\begin{array}{l}\text { Irrigation District } \\
\text { ID }\end{array}$} & \multirow[t]{2}{*}{ Municipalities } & \multirow{2}{*}{$\begin{array}{l}\text { Field } \\
\text { Plots }\end{array}$} & \multirow{2}{*}{$\begin{array}{l}\text { Area } \\
\text { (ha) }\end{array}$} & \multicolumn{4}{|c|}{$\mathrm{N}^{\circ}$ satellite images } \\
\hline & & & & 2014 & 2015 & 2016 & 2017 \\
\hline \multirow{4}{*}{$\begin{array}{l}\text { Canal Simancas, } \\
\text { Geria and } \\
\text { Villamarciel } \\
\text { de Tordesillas } \\
\text { (SGVT) }\end{array}$} & Geria & 7 & 11 & 5 & 5 & 15 & 18 \\
\hline & Simancas & 17 & 22 & 6 & 5 & 18 & 20 \\
\hline & Tordesillas & 20 & 30 & 5 & 4 & 14 & 20 \\
\hline & Total & 44 & 63 & 16 & 14 & 47 & 58 \\
\hline Canal Toro & Coreses & 10 & 28 & 11 & 16 & 33 & 37 \\
\hline \multirow[t]{5}{*}{$\begin{array}{l}\text { Zamora } \\
\text { (CTZ) }\end{array}$} & $\begin{array}{l}\text { Fresno de la } \\
\text { Ribera }\end{array}$ & 10 & 28 & 11 & 16 & 33 & 36 \\
\hline & $\begin{array}{l}\text { San Roman de } \\
\text { Hornija }\end{array}$ & 10 & 30 & 6 & 6 & 14 & 20 \\
\hline & Toro & 10 & 40 & 11 & 16 & 30 & 41 \\
\hline & Zamora & 10 & 36 & 10 & 14 & 27 & 37 \\
\hline & Total & 50 & 162 & 49 & 68 & 137 & 161 \\
\hline \multirow[t]{5}{*}{$\begin{array}{l}\text { Canal Villagonzalo } \\
\quad \text { (CVG) }\end{array}$} & $\begin{array}{l}\text { Calvarrasa } \\
\text { Abajo }\end{array}$ & 10 & 25 & 10 & 15 & 21 & 28 \\
\hline & Machacon & 10 & 29 & 15 & 19 & 24 & 34 \\
\hline & Pelabravo & 10 & 24 & 22 & 33 & 35 & 47 \\
\hline & Villagonzalo & 10 & 32 & 6 & 8 & 15 & 19 \\
\hline & Total & 40 & 110 & 53 & 75 & 95 & 128 \\
\hline $\begin{array}{l}\text { Villalar } \\
\text { Comuneros, }\end{array}$ & $\begin{array}{l}\text { Villalar de los } \\
\text { Comuneros }\end{array}$ & 9 & 25 & 6 & 4 & 12 & 26 \\
\hline $\begin{array}{l}\text { Sector I } \\
\text { (VC) }\end{array}$ & Total & 9 & 25 & 6 & 4 & 12 & 26 \\
\hline TOTAL & 13 & 143 & 360 & 124 & 161 & 291 & 373 \\
\hline
\end{tabular}

sunflower irrigated by sprinkler irrigation and with a full coverage during the maximum growth stage. Since the climatic conditions of this region are similar to the one in Castilla León region, it has been recommended by the Irrigation Advisory Center SIAR. Likewise, Toureiro et al. (2017) stated that if an empirical equation is reliable for a given crop and region, it may be applied to define the crop water balance parameters from remote sensed data, instead of using the corresponding 
Table 2

Information of the imagery dataset used in the study area.

\begin{tabular}{|c|c|c|c|c|c|}
\hline Satelliter & & $\begin{array}{l}\text { Ground sample } \\
\text { distance } \\
\text { (m) }\end{array}$ & $\begin{array}{l}\text { Revisit time } \\
\text { (d) }\end{array}$ & $\begin{array}{l}\text { Visual field } \\
(\mathrm{km})\end{array}$ & Launching date \\
\hline Landsat8 & & 30 & 16 & 185 & $11 / 02 / 2013$ \\
\hline \multirow[t]{2}{*}{ Sentinel 2} & $\mathrm{~S} 2 \mathrm{~A}$ & 10 & 5 & 290 & $23 / 06 / 2015$ \\
\hline & S2B & & & & $07 / 03 / 2017$ \\
\hline
\end{tabular}

in situ parameters, which are harder and expensive to obtain. Thus, Eq. (3) was used to determine Kc values in this work.

$K c_{\text {satellite }}=1.25 * N D V I+0.2$

The corn Kc coefficient and its temporal and spatial variability, across municipalities and irrigation districts, were determined (Eq. (3)) for 2014, 2015, 2016 and 2017. The satellite images were collected every 3 or 15 days, and every image corresponded the Kc value for that specific day, so the sequence of Kc values describes the temporal variability of $\mathrm{Kc}$ during the crop cycle $\left(\mathrm{Kc}_{\text {satellite }}\right)$. Satellite images with clouds were deleted.

The Kc values obtained were fitted to a growth stages curve and finally, the crop coefficient values for initial development $\left(\mathrm{Kc}_{\mathrm{ini}}\right)$, midseason $\left(\mathrm{Kc}_{\mathrm{mid}}\right)$ and end-season $\left(\mathrm{Kc}_{\mathrm{end}}\right)$ were calculated as a mean $\mathrm{Kc}$ coefficient for every stage of crop development crop. Thus, three Kc calculated coefficients were calculated, each of them was considered constant within the crop phenology stage (Allen et al., 1998), and then, they were adjusted to a Kc fitted curve.

The variability at the field plot scale is not considered in this study since its objective is to determine representative Kc coefficients for all farmers, and not for specific ones, in the studied areas. Even these coefficients could be advisable the farmers who didn't grow corn during the studied period but could do it in the future.

\subsection{Water use efficiency and irrigation supply}

\subsubsection{Water use efficiency indicators}

Water use efficiency was assessed by the dimensionless indicators: annual relative irrigation supply (ARIS,), annual relative water supply (ARWS), relative rainfall supply (RRS) (Droogers et al., 2000; Clemmens and Molden, 2007; Lorite et al., 2004a), expressed in annual basis. They are defined as follows:

ARIS $=\frac{I W S\left[m^{3} / \mathrm{Ha}\right]}{\operatorname{GIR}\left[\mathrm{m}^{3} / \mathrm{Ha}\right]}$

$A R W S=\frac{I W S\left[m^{3} / H a\right]+P e\left[m^{3} / H a\right]}{E T\left[m^{3} / H a\right]}$

$R R S=\frac{P e[\mathrm{~mm}]}{E T[\mathrm{~mm}]}$

Where: IWS is the irrigation water supply; GIR is the gross irrigation requirements; $\mathrm{Pe}$ is the effective precipitation, and ET is the crop evapotranspiration.

ET will depend on the climatic conditions, soil water availability and crop growth. It was calculated by the FAO-56 model (Allen et al., 1998)

$\mathrm{ET}=\mathrm{ETo} * \mathrm{Kc}$

Where ETo $(\mathrm{mm})$ is the reference evapotranspiration corresponded to an ideal crop with standard crop parameters, and Kc is the crop coefficient (dimensionless).

The ETo is calculated by the Penman-Monteith equation with requires typical meteorology data such as solar radiation, wind speed, temperature and air humidity. Daily data of these variables were downloaded from the Spanish Agroclimatic Information System for
Irrigation (SIAR) for each ID and during the study period 2014-2017. The dataset came from the closest climatic stations in each ID (Ejeme, Toro, Tordesillas and Rueda).

\subsubsection{Irrigation requirements}

The net (NIR) and the gross (GIR) irrigation requirements were calculated as:

$N I R=E T-P e$

ET and Pe were converted from $\mathrm{mm}$ to $\mathrm{m}^{3} / \mathrm{ha}$, to obtain NIR and GIR in $\mathrm{m}^{3} /$ ha.

$G I R=\frac{N I R * 100}{E a}$

Where: Ea is the irrigation efficiency, which was considered $85 \%$ according to the field evaluation of the irrigation systems in the region carried out by Naroua et al. (2012). Additionally, the irrigation district managers state that the common irrigation efficiency (Ea) is about $85 \%$ with a leaching fraction close to $5 \%$. The accuracy of these values could not be validated in this work. Nevertheless, it is expected that they may be close to local actual values thus, they have been considered in the present study instead of the values reported for other regions.

The Pe was determined as a percentage of the total precipitation logged in the agro-climatic stations that calculate it automatically.

For each municipality and irrigation district, the GIR values were compared with the IWS provided by the irrigation district's managers, with the WUE indicators.

3.3.3. Comparison between the estimated and recommended irrigation requirements

The Irrigation Advisory Service from the regional technological agronomic institute of Castilla and León (ITACyL) supports farmers' decisions on irrigation's management though the irrigation regional platform InfoRiego. It gathers the agro-climatic data from several weather stations throughout the region. Thus, farmers can estimate the irrigation requirements for each crop growth stage.

The estimation of irrigation requirements is based on the determination of crop water requirements ET and for that, the Kc coefficients are needed (see Eq. (5)). The corn coefficients suggested by ITACyL $\left(\mathrm{Kc}_{\mathrm{ITACyL}}\right)$ do not consider factors such as: soil variation, cultural practices, crop phenology and climate that varied from one zone to other (ITACyL, 2012). These could affect the proper ET estimation since the local Kc are not known. Likewise, it might also result in an underestimation of water requirements in some areas and overestimation in others. Consequently, the assessment of water use efficiency among municipalities (in every ID) and among IDs will be beneficial to guide the decisions for water allocation and irrigation management.

ITACyL has only validated Kc coefficients for sugar beet in the region, and it recommends the coefficients from the FAO datasets for other crops. Thus, a statistical analysis has been performed to know if the Kc values determined in this work are significant different from the ITACyL. Their effect on the calculation of irrigation requirements was also analyzed using the Student $t$-test.

\subsection{Statistical analysis}

The Root Mean Square Error (RMSE, Eq. (11)) was used to test the differences between the $\mathrm{Kc}_{\text {satellite }}$ and $\mathrm{Kc}_{\text {ITACyL }}$ values.

$R M S E=\left[\frac{\sum_{i=1}^{i=n}\left(k c_{\text {ITACyL }}-k c_{\text {satellite }}\right)_{i}^{2}}{n}\right]^{1 / 2}$

Where: $\mathrm{i}=$ year and $\mathrm{n}=$ number of satellite data.

Since the Kc estimations, for each municipality, were obtained from different number of cloud-free satellite data (see Table 1), their effect on temporal Kc calculation was also assessed by the RMSE. 


\begin{tabular}{|crrrr|}
\hline $\mathrm{T}\left({ }^{\circ} \mathrm{C}\right):$ & $\mathrm{SGVT}$ & $\mathrm{CTZ}$ & $\mathrm{CVG}$ & $\mathrm{VC}$ \\
$\mathrm{P}(\mathrm{mm}):$ & $-\mathrm{SGVT}$ & $--\mathrm{CTZ}$ & $\ldots-\cdots \mathrm{CVG}$ & $-\cdots-\mathrm{VC}$ \\
\hline
\end{tabular}
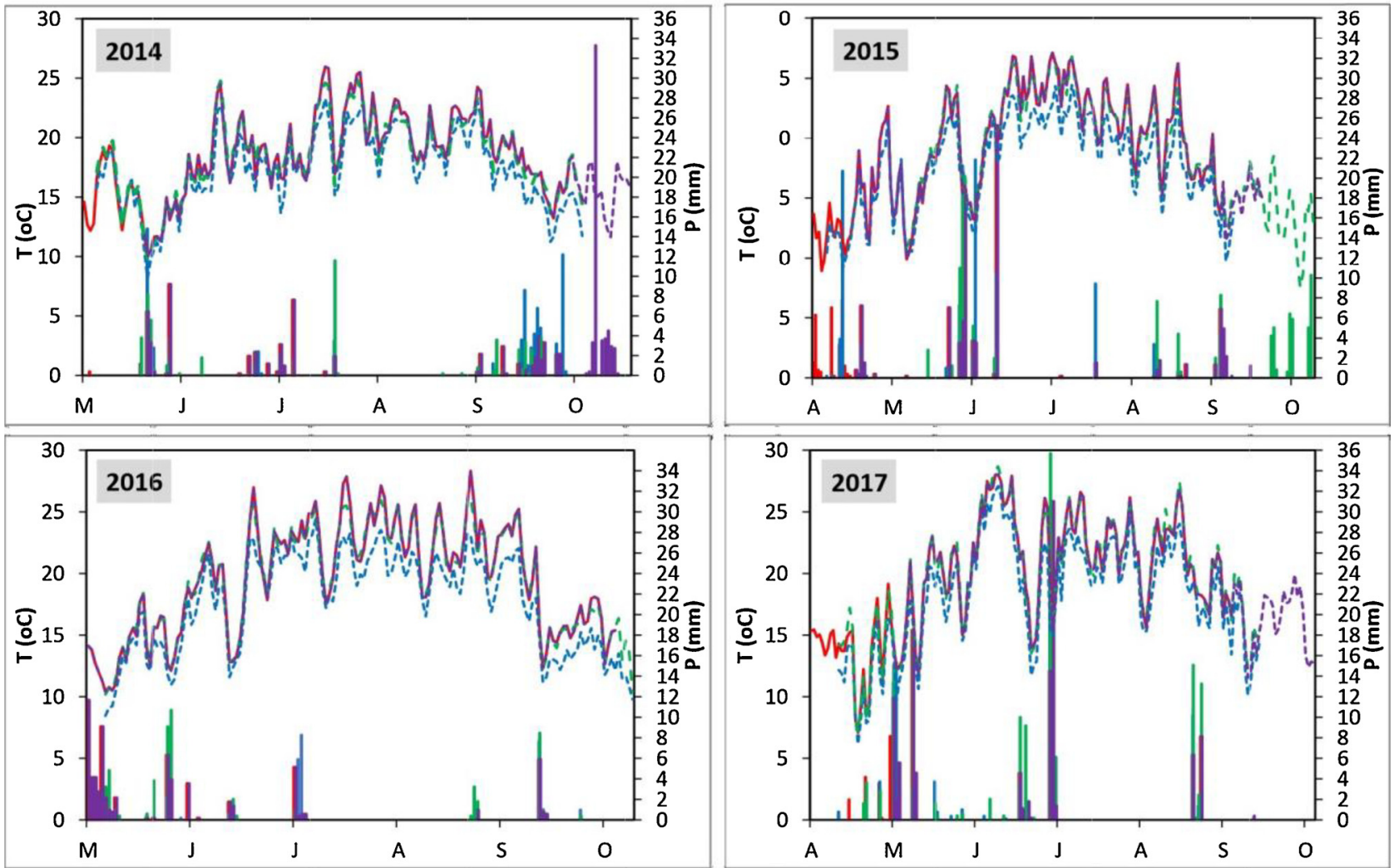

Fig. 2. Seasonal trends of mean temperature (T) and precipitation (P) values during the corn growing period for 2014, 2015, 2016 and 2017.
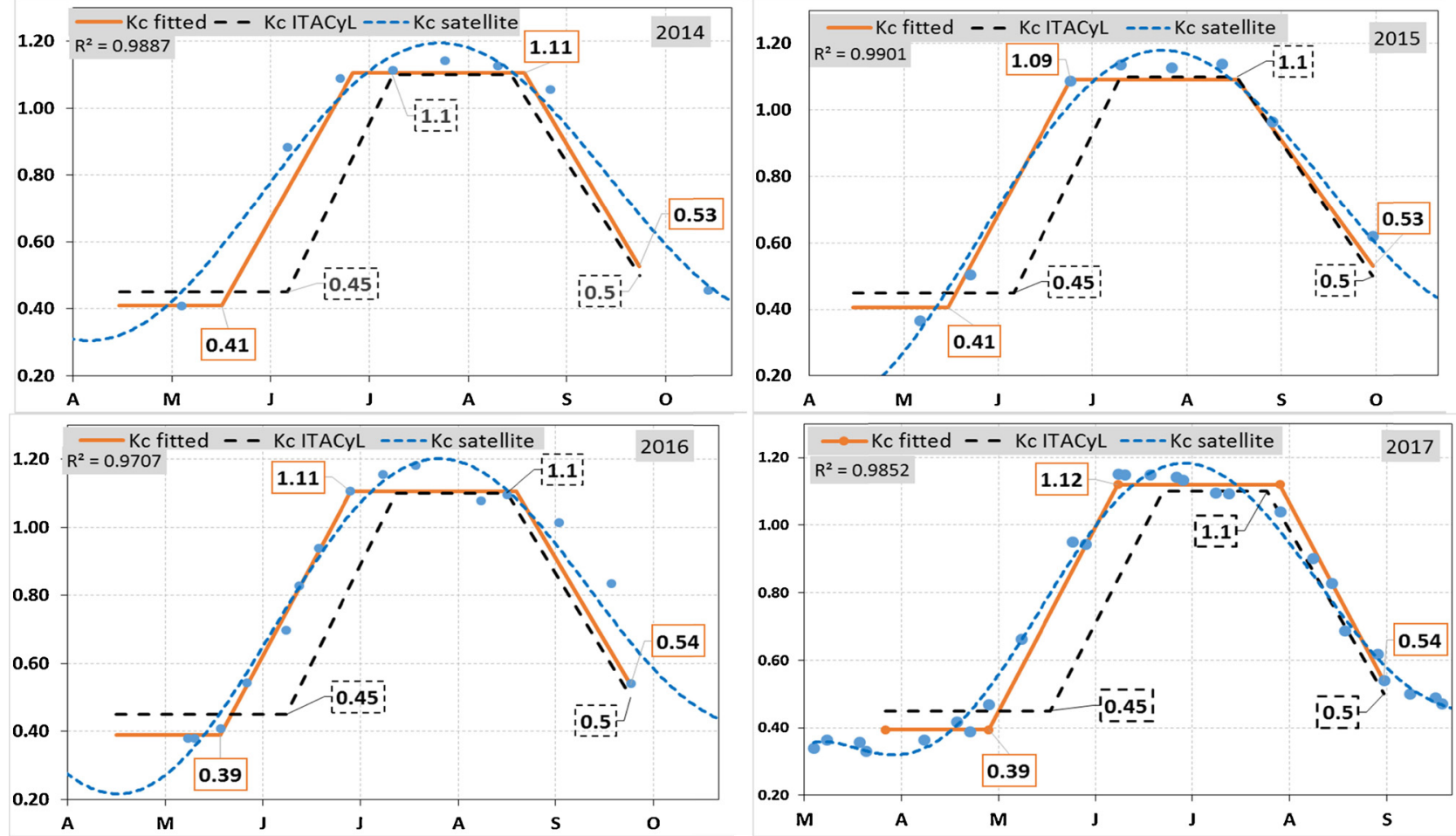

Fig. 3. Temporal evolution of fitting curves for the Kc values obtained by satellital imagery for the municipality of Villagonzalo (CVG irrigation district), and the ITACYL recommendations. 
Spatial and temporal differences on crop coefficients were tested by the ANOVA test. The differences, both among field plots within the ID and in the mean Kc values within the corn growth stages and IDs, were studied.

\section{Results and discussion}

\subsection{Climatic variables}

The study area presents a continental Mediterranean climatic regime with a rainy winter and spring, and dry summer. The highest temperatures $\left(25-28^{\circ} \mathrm{C}\right)$ corresponded to the summer months June to August which also show the highest irrigation demand (high evapotranspiration and negligible rainfall).

Fig. 2 presents the seasonal trend of mean temperature (rows) and precipitation (columns) for the four IDs, during the physiology corn cycle (May to October), and the four irrigation seasons. The temperature variation was smaller than precipitation among IDs.

In 2015 and 2017, the precipitation was higher than in the other two years. The major rainfalls corresponded to May, June, September and October (especially in May with $10-20 \mathrm{~mm} /$ event) although they decreased in the last two months for 2016 and 2017. Consequently, this variability affected both the water storage in the irrigation reservoirs, and the corn water requirements during the growing season.

\subsection{Corn crop coefficients}

The fitted Kc curves across corn growth stages were obtained with the local corn Kc estimated for each municipality. They showed a very good fit and their coefficients of determination $\mathrm{R}^{2}$ varied from 0.97 to 0.99 . The standard deviation values ranged from 0.01 to 0.03 , indicating an adequate stability and fairly tight dispersion in the datasets. As an example, Fig. 3 shows the temporal evolution of fitting curves for Villagonzalo (CVG) and the $\mathrm{Kc}_{\mathrm{ITACy}}$ recommended by ITACYL. The results for the remainder IDs were similar and are not shown. The pattern for the fitted Kc curves behaves similarly within the study period. Likewise, it is observed that the fitted and the $\mathrm{Kc}_{\text {ITACYL }}$ values were close. However, the last moved ahead in the transition between the initial to the mid-season stages since ITACYL considers a longer initial stage and a shorter mid-season stage (see Table 3).

The corn growth stages' length coincided with the recommendation by FAO (Allen et al., 1998) for the Castilla and León region, although it was different from the ITACyL's value (see Table 3).

Table 4 depicts the average corn coefficient Kc for the IDs, and their municipalities, obtained with the methodology described in section 3.2. Likewise, it also presents the values for the crop`s growth stages: initial $\left(\mathrm{Kc}_{\mathrm{ini}}\right)$, mid-season $\left(\mathrm{Kc}_{\mathrm{mid}}\right)$ and end-season $\left(\mathrm{Kc}_{\mathrm{end}}\right)$.

For the study period, the mean crop coefficients among IDs were: $\mathrm{Kc}_{\text {ini }}=0.41 \pm 0.01, \mathrm{Kc}_{\text {mid }}=1.08 \pm 0.01$ and $\mathrm{Kc}_{\text {end }}=0.55 \pm 0.01$. These were slightly different to the recommendations by the Advisory Irrigation Services ITACYL $\left(\mathrm{Kc}_{\mathrm{ini}}=0.45, \mathrm{Kc}_{\mathrm{mid}}=1.1\right.$ and $\left.\mathrm{Kc}_{\mathrm{end}}=0.5\right)$. Among others, these results might be caused by the different approach followed for their calculation. ITACYL values are constant and do not take into account differences in soil, weather, phenology stage, cultural practice for each ID, while this work estimate them for local conditions using satellite imagery.

Table 3

Duration of corn growth stages.

\begin{tabular}{llllll}
\hline Reference & $\begin{array}{l}\text { Initial } \\
\text { stage } \\
\text { (d) }\end{array}$ & $\begin{array}{l}\text { Crop development } \\
\text { (d) }\end{array}$ & $\begin{array}{l}\text { Mid-season } \\
\text { (d) }\end{array}$ & $\begin{array}{l}\text { End-season } \\
\text { (d) }\end{array}$ & $\begin{array}{l}\text { Growth } \\
\text { stages (d) }\end{array}$ \\
\hline FAO & 30 & 40 & 50 & 32 & 152 \\
ITACyL & 50 & 35 & 32 & 35 & 152 \\
\hline
\end{tabular}

Also, no significant error could be expected in estimating the kc coefficients from the fitted curves from satellite data and ITACYL recommendations. The Root Mean Square Error (RMSE) values were small within the range 0.037 to 0.106 (see Table 5).

The effect of the number of satellite images (n) on Kc estimation (expressed by RMSE) is shown in Fig. 4. The $\mathrm{n}$ values scattered from 5 to 48 within a RMSE ranged from 0.038 to 0.108 . No linear relation was observed between both variables (linear correlation coefficient $\rho=-$ 0.03). Furthermore, a RMSE value about 0.06 corresponded to the worst situation (minimum $\mathrm{n}$ value). Therefore, the number of cloud free satellite data did not affect the Kc estimations reinforcing the results presented in this paper.

The results assessing the variability of Kc values among field plots in each municipality are shown in Table 6 . For most plots, corn coefficients could not be considered different (high p-values). Thus, if the significant level is fixed at 5\%, the Kc at field plots in Simancas, F. de la Ribera, Toro and Zamora (2017)and Coreses (2016) would be different. However if the significant level is $1 \%$, the kc would be different only in the first three municipalities. It is worth to note that not all the field plots had the same satellite dataset, and it could have affected the determination of $\mathrm{p}$ values. Moreover, the results might be also conditioned by the particularities of each plot (soil properties, crop canopy, micro agroclimatic conditions) in some municipalities, and especially for differences in crop management. As a result, for each municipality and during the study period, the Kc values could be considered similar among field plots

Table 7 presents the results of the statistical tests comparing the mean crop coefficients among the IDs for different growth stages. The high values mean a higher probability for all the IDs' values to be the same. It is observed, that mean Kc values could be considered similar among IDs for each year and corn growth stage. The smaller probabilities corresponded to the mid-season $\mathrm{Kc}_{\text {mid }}$ although they are not statistically significant. Thus, the estimation of the maximum water demands for this growth stage would also show small differences.

\subsection{Crop water requirements}

\subsubsection{Evolution of reference evapotranspiration ETo and evapotranspiration ET}

The sowing date has an effect on the cumulated ETo during the growing period and thus, in the ET. If the period with the highest crop water requirements (mid-season stage, Kcmid) coincides with the highest atmospheric demand (June-July-August), the irrigation needs will be higher. In conclusion, the sowing date will have an impact on the water demand during the crop growth cycle.

The temporal evolution of Kc fitted curves and ETo for the growing season is shown in Fig. 5. The sowing dates ranged between April and May although for each growing season, they varied not only among IDs but within plots in the same municipality. Plots with the sowing date in April would show higher ETo demand than those sowed in May. Thus as a very late, sowing should be done in May to reduce water consumption although if it is further delayed, the end crop stage might coincide with the frost season.

Regarding the above, the SGVT was the irrigation district with the earliest sowing dates and therefore, the highest ETo. Conversely, the irrigation district VC had the latest showing dates and consequently, the lowest ETo. It is highlighted that in 2015 and 2017 the rainfall was concentrated in a few events, and the water level in the irrigation reservoirs were below the average when the crop most need it. Thus in all IDs, except VC, the sowing dates came early than usual due to the uncertainty of water availability. However, the irrigation district VC did not change the sowing dates since the water from irrigation are pumped from wells which phreatic level was not affected.

The corn water requirements ET were calculated with Eq. (7) and their temporal tendency, together with ETo, is presented in Fig. 6.

The annual ETo values varied between 560 and $650 \mathrm{~mm}$ among IDs, 
Table 4

Average corn coefficients among irrigation districts, and their municipalities, during the study period.

\begin{tabular}{|c|c|c|c|c|c|c|c|c|c|c|c|c|c|}
\hline \multirow[b]{2}{*}{ ID } & \multirow[b]{2}{*}{ Municipality } & \multicolumn{4}{|c|}{$\mathrm{Kc}_{\text {ini }}(*)$} & \multicolumn{4}{|c|}{$\mathrm{Kc}_{\text {mid }}(*)$} & \multicolumn{4}{|c|}{$\mathrm{Kc}_{\text {end }}(*)$} \\
\hline & & 2014 & 2015 & 2016 & 2017 & 2014 & 2015 & 2016 & 2017 & 2014 & 2015 & 2016 & 2017 \\
\hline \multirow[t]{5}{*}{ SGVT } & Geria & 0.42 & 0.42 & 0.45 & 0.39 & 1.03 & 1.04 & 1.02 & 1.05 & 0.54 & 0.53 & 0.52 & 0.58 \\
\hline & Simancas & 0.42 & 0.42 & 0.43 & 0.39 & 1.07 & 1.04 & 1.06 & 1.06 & 0.53 & 0.51 & 0.53 & 0.54 \\
\hline & Tordesillas & 0.40 & 0.40 & 0.41 & 0.40 & 1.05 & 1.00 & 1.07 & 1.05 & 0.53 & 0.52 & 0.53 & 0.51 \\
\hline & Mean & 0.41 & 0.41 & 0.43 & 0.40 & 1.05 & 1.03 & 1.05 & 1.05 & 0.53 & 0.52 & 0.52 & 0.54 \\
\hline & ID mean & \multicolumn{4}{|c|}{$0.41 \pm 0.02$} & \multicolumn{4}{|c|}{$1.05 \pm 0.02$} & \multicolumn{4}{|c|}{$0.53 \pm 0.02$} \\
\hline \multirow[t]{7}{*}{ CTZ } & Coreses & 0.41 & 0.38 & 0.37 & 0.36 & 1.08 & 1.13 & 1.11 & 1.10 & 0.54 & 0.56 & 0.54 & 0.58 \\
\hline & F. de la Rivera & 0.43 & 0.39 & 0.40 & 0.38 & 1.11 & 1.04 & 1.07 & 1.05 & 0.54 & 0.54 & 0.56 & 0.57 \\
\hline & San Roman H. & 0.39 & 0.39 & 0.42 & 0.36 & 1.07 & 1.08 & 1.08 & 1.08 & 0.51 & 0.58 & 0.59 & 0.51 \\
\hline & Toro & 0.44 & 0.45 & 0.41 & 0.47 & 1.08 & 1.07 & 1.08 & 1.09 & 0.57 & 0.54 & 0.56 & 0.56 \\
\hline & Zamora & 0.44 & 0.40 & 0.40 & 0.38 & 1.10 & 1.13 & 1.11 & 1.12 & 0.53 & 0.53 & 0.55 & 0.54 \\
\hline & Mean & 0.42 & 0.40 & 0.40 & 0.39 & 1.09 & 1.09 & 1.09 & 1.09 & 0.54 & 0.55 & 0.56 & 0.55 \\
\hline & ID mean & \multicolumn{4}{|c|}{$0.42 \pm 0.03$} & \multicolumn{4}{|c|}{$1.09 \pm 0.02$} & \multicolumn{4}{|c|}{$0.55 \pm 0.02$} \\
\hline \multirow[t]{6}{*}{ CVG } & Calvarrasa Abajo & 0.40 & 0.42 & 0.36 & 0.36 & 1.10 & 1.10 & 1.12 & 1.13 & 0.55 & 0.55 & 0.53 & 0.57 \\
\hline & Machacon & 0.37 & 0.40 & 0.37 & 0.37 & 1.11 & 1.13 & 1.12 & 1.12 & 0.52 & 0.56 & 0.54 & 0.53 \\
\hline & Pelabravo & 0.43 & 0.40 & 0.39 & 0.35 & 1.10 & 1.11 & 1.13 & 1.11 & 0.57 & 0.57 & 0.58 & 0.56 \\
\hline & Villagonzalo & 0.41 & 0.41 & 0.39 & 0.39 & 1.11 & 1.09 & 1.11 & 1.12 & 0.53 & 0.53 & 0.54 & 0.54 \\
\hline & Mean & 0.40 & 0.41 & 0.38 & 0.37 & 1.10 & 1.11 & 1.12 & 1.12 & 0.54 & 0.55 & 0.55 & 0.55 \\
\hline & ID mean & \multicolumn{4}{|c|}{$0.39 \pm 0.02$} & \multicolumn{4}{|c|}{$1.11 \pm 0.01$} & \multicolumn{4}{|c|}{$0.55 \pm 0.02$} \\
\hline \multirow[t]{2}{*}{ VC } & Villalar Comu. & 0.43 & 0.37 & 0.44 & 0.41 & 1.07 & 1.03 & 1.07 & 1.08 & 0.59 & 0.53 & 0.56 & 0.56 \\
\hline & ID mean & \multicolumn{4}{|c|}{$0.41 \pm 0.03$} & \multicolumn{4}{|c|}{$1.06 \pm 0.02$} & \multicolumn{4}{|c|}{$0.56 \pm 0.02$} \\
\hline \multicolumn{2}{|c|}{ Mean value per year } & 0.42 & 0.40 & 0.41 & 0.39 & 1.08 & 1.06 & 1.08 & 1.08 & 0.55 & 0.54 & 0.55 & 0.55 \\
\hline \multicolumn{2}{|c|}{ Mean value } & \multicolumn{4}{|c|}{$0.41 \pm 0.01$} & \multicolumn{4}{|c|}{$1.08 \pm 0.01$} & \multicolumn{4}{|c|}{$0.55 \pm 0.01$} \\
\hline
\end{tabular}

(*) $\mathrm{Kc}_{\mathrm{ini}} ; \mathrm{Kc}_{\mathrm{mid}}$ and $\mathrm{Kc} \mathrm{end}_{\mathrm{e}}=$ crop value corresponding to the initial, mid-season and end-season corn stages.

Table 5

Values of the Root Mean Square Error (RMSE) for the comparison of fitted Kc and ITACYL recommendation in the Villagonzalo irrigation district during the study period.

\begin{tabular}{|c|c|c|c|c|c|}
\hline \multirow[t]{2}{*}{ ID } & \multirow[t]{2}{*}{ Municipality } & \multicolumn{4}{|l|}{ RMSE } \\
\hline & & 2014 & 2015 & 2016 & 2017 \\
\hline \multirow[t]{3}{*}{ SGVT } & Geria & 0.075 & 0.060 & 0.077 & 0.106 \\
\hline & Simancas & 0.066 & 0.061 & 0.047 & 0.056 \\
\hline & Tordesillas & 0.066 & 0.045 & 0.054 & 0.064 \\
\hline \multirow[t]{5}{*}{ CTZ } & Coreses & 0.104 & 0.066 & 0.070 & 0.061 \\
\hline & F. de la Rivera & 0.053 & 0.049 & 0.061 & 0.060 \\
\hline & San Roman de H. & 0.067 & 0.086 & 0.048 & 0.096 \\
\hline & Toro & 0.064 & 0.045 & 0.063 & 0.081 \\
\hline & Zamora & 0.104 & 0.066 & 0.070 & 0.061 \\
\hline \multirow[t]{4}{*}{ CVG } & Calvarrasa Abajo & 0.065 & 0.080 & 0.058 & 0.053 \\
\hline & Machacon & 0.081 & 0.044 & 0.064 & 0.037 \\
\hline & Pelabravo & 0.082 & 0.093 & 0.089 & 0.063 \\
\hline & Villagonzalo & 0.073 & 0.053 & 0.053 & 0.046 \\
\hline VC & Villalar de los C. & 0.065 & 0.074 & 0.078 & 0.073 \\
\hline
\end{tabular}

and their temporal difference was less than $50 \mathrm{~mm}$. Likewise, for each ID the highest difference was about $70 \mathrm{~mm}$ /year (CTZ). The accumulate ET was always less than the ETo.

\subsection{Evolution of irrigation requirements}

Fig. 7 shows the temporal and spatial variability in Pe during the crop cycle among IDs.

The cumulated effective precipitation during the growing period was higher for 2015 and 2017 than in the other years (see Fig. 7). The highest value corresponded to the CTZ with $83 \mathrm{~mm} \mathrm{(2017)}$ and the lowest value $12 \mathrm{~mm}$ in CVG (2016). Rainfall could not fulfil the corn water requirements and irrigation was needed.

Table 8 displays the temporal evolution of the gross irrigation requirements (GIR) calculated with Eq. (6) comparing the values obtained with $\mathrm{Kc}_{\text {satellite }}$ and $\mathrm{Kc}_{\mathrm{ITACyL}}$.

During the study period, the NIR varied from 5180 and $6110 \mathrm{~m}^{3} /$ ha and the GIR from 6476 and $7646 \mathrm{~m}^{3} /$ ha. The highest and lowest average GIR value corresponded to SGVT $\left(7387 \mathrm{~m}^{3} /\right.$ year) and VC $\left(7009 \mathrm{~m}^{3} /\right.$ year), respectively. However, the spatial and temporal differences were small. For each ID, their temporal and spatial coefficient of variation $\mathrm{CV}$ ranged from 0.01 to 0.06 , and from 0.03 to 0.05 , respectively.

The mean GIR calculated by the $\mathrm{Kc}_{\mathrm{ITACyL}}$ for all IDs in the Duero river basin were smaller than the ones estimated with $\mathrm{Kc}_{\text {satellite }}$ and varied between $5882 \mathrm{~m} 3$ / year (CTZ) and $6904 \mathrm{~m} 3 /$ year (SGVT). The temporal coefficient of variation was within the interval 0.01 and 0.07 , and the spatial variation within 0.03 and 0.08 . These differences were slightly higher than the ones estimated by the $\mathrm{Kc}_{\text {satellite }}$ proposed in this work for local conditions. Likewise, the Student $t$-test $(\mathrm{p}=0.002)$ indicates that GIR estimations for corn in the region, calculated with $\mathrm{Kc}_{\text {satellite }}$ and $\mathrm{Kc}_{\mathrm{ITACyL}}$, are significantly different. Thus, GIR will depend on whether $\mathrm{Kc}_{\text {satellite }}$ or $\mathrm{Kc}_{\mathrm{ITAC} \mathrm{L}}$ is used; the last underestimated it.

The comparison between GIR ( $\left.\mathrm{Kc}_{\text {satellite }}\right)$ and the actual irrigation water supply IWS, provided by the irrigation district managers, is shown in Fig. 8. Some differences among IDs are observed. Thus in CTZ and CVG, the IWS did not fulfil the GIR, except for 2015 and CTZ (where it slightly exceed the needs). On the contrary, in SGVT overirrigation was observed in all years except 2017 in which a high deficit irrigation was observed together with CTZ. In the irrigation VC, the IWS fulfil the GIR and it showed clearly over in irrigation for 2017. It is note that the irrigation district VC performed over irrigation in 2017 where the others districts performed a severe deficit irrigation. As it was pointed in 4.3.1, this district irrigates with subsurface water which level was not affected but the shortage storage in the irrigation reservoirs.

\subsection{Water use efficiency for corn}

The results for the corn water use efficiency indicators are shown in Fig. 9.

ARIS values (Eq. 4) close to 1 show and optimal irrigation management; ARIS $<1$ highlight deficit irrigation and ARIS $>1$ over irrigation. As further the ARIS value drops below 1, as severe the water stress suffered by the crop and thus, a lesser crop yield by an inadequate irrigation management.

The ARIS indicator spread within a wide interval from 0.59 to 1.18. Their values were mostly higher than the values ( 0.73 to 0.91 ) reported in Southern Spain IDs by Lorite et al. (2004b) but they were similar 


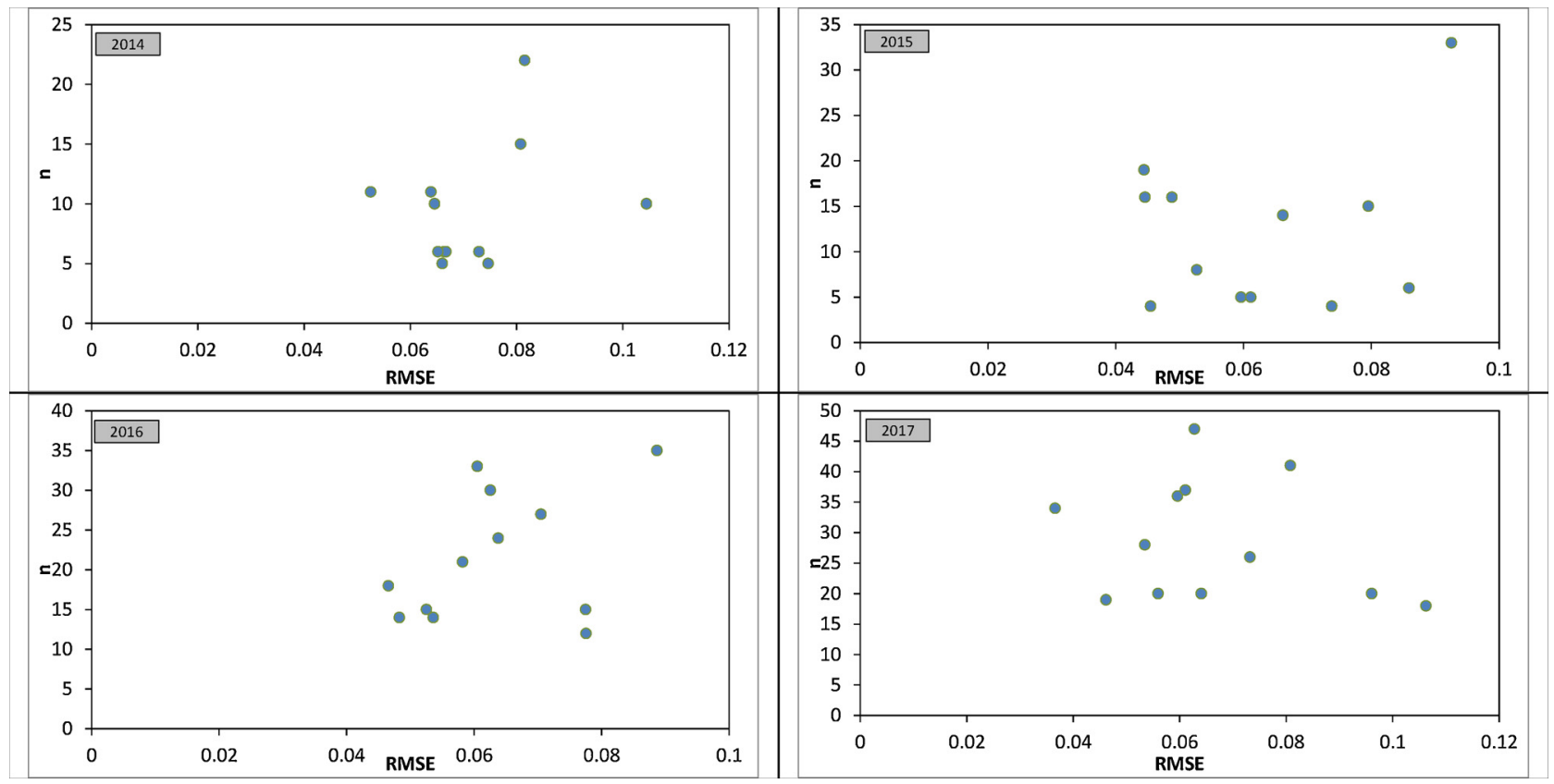

Fig. 4. Variation of Kc, root mean square error values, with the number of cloud-free satellite data used for their estimation.

Table 6

Values of $\mathrm{p}$ from the ANOVA test to assess the crop coefficient spatial differences among field plots, within the municipality, for the study period.

\begin{tabular}{|c|c|c|c|c|c|}
\hline \multirow[t]{2}{*}{ ID } & \multirow[t]{2}{*}{ Municipality } & \multicolumn{4}{|l|}{ p-value } \\
\hline & & 2014 & 2015 & 2016 & 2017 \\
\hline \multirow[t]{3}{*}{ SGVT } & Geria & 0.984 & 0.966 & 0.921 & 0.606 \\
\hline & Simancas & $1.000^{\mathrm{a}}$ & $1.000^{\mathrm{a}}$ & 0.997 & 0.001 \\
\hline & Tordesillas & $1.000^{\mathrm{a}}$ & $1.000^{\mathrm{a}}$ & 0.884 & 0.940 \\
\hline \multirow[t]{5}{*}{ CTZ } & Coreses & 0.963 & $1.000^{\mathrm{a}}$ & 0.023 & 0.237 \\
\hline & F. de la Rivera & 0.985 & 0.997 & 0.345 & $0.000^{\mathrm{a}}$ \\
\hline & San Roman de H. & 0.998 & 0.999 & 0.937 & 0.840 \\
\hline & Toro & 0.532 & 0.586 & 0.066 & $0.000^{\mathrm{a}}$ \\
\hline & Zamora & 0.931 & 0.996 & 0.850 & $0.000^{\mathrm{a}}$ \\
\hline \multirow[t]{4}{*}{ CVG } & Calvarrasa Abajo & $1.000^{\mathrm{a}}$ & 0.891 & 0.400 & 0.892 \\
\hline & Machacon & $1.000^{\mathrm{a}}$ & 0.999 & 0.999 & $1.000^{\mathrm{a}}$ \\
\hline & Pelabravo & 0.938 & 0.999 & 0.941 & 0.407 \\
\hline & Villagonzalo & $1.000^{\mathrm{a}}$ & $1.000^{\mathrm{a}}$ & $1.000^{\mathrm{a}}$ & $1.000^{\mathrm{a}}$ \\
\hline VC & Villalar Comun. & 0.952 & 0.998 & 0.649 & 0.913 \\
\hline
\end{tabular}

${ }^{a}$ values greater than 0.9999 or lesser than 0.0000 have been written as 1.000 and 0.000 , respectively.

Table 7

Values of p (ANOVA test) to address the differences in the mean corn coefficients for different growth stages (among IDs) during the study period.

\begin{tabular}{lllll}
\hline & 2014 & 2015 & 2016 & 2017 \\
\hline Kcin & 0.98 & 1.00 & 0.98 & 0.45 \\
kcmid & 0.68 & 0.54 & 0.51 & 0.52 \\
kcend & 0.99 & 0.98 & 1.00 & 0.68 \\
\hline
\end{tabular}

than the ones for Central Spain reported by Naroua et al. (2014). Nevertheless, in 2017 the values in SGVT and CTZ were smaller than those obtained for these authors, although were similar to the ones determined by Lorite et al. (2004a). The highest value corresponded to SGVT (2014), and the smallest to CTZ (2017).

The CVG district showed ARIS values more uniform followed by the VC district. Deficit irrigation was performed in CTZ and CVG, except for CTZ in 2015. Likewise, over irrigation was performed in SGVT (2014 and 2016), and VC (2014 and 2017). An optimum irrigation was observed in SGVT (2015) and VC (2016) although the last district presented a slightly deficit irrigation (2015). For 2017, the ARIS values decreased in all IDs except VC. The highest decrease corresponded to SGVT followed by CTZ. As it was commented above, VC behaved different since they use subsurface water which phreatic level was not affected by the level of water storage in the irrigation reservoirs. Thus, its availability for water resources was higher than in other IDs, which used surface water to fulfil their reservoirs and had constrained their water resources for irrigation.

The deficit irrigation observed in CTZ and CVG could be explained by the GIR underestimation when using $\mathrm{Kc}_{\mathrm{ITACyL}}$. Even though, if the allocation of water for irrigation were higher than estimated, and also both irrigation districts over irrigated the corn, these facts would highlight that irrigator managers do not follow the guidelines from the Advisory Irrigation Center ITACyL.

The ARWS indicator (Eq. (5)) indicates if water supplied to the crop (irrigation plus effective precipitation) covers its water requirements (ET); it varies from 0.77 to 1.47 among IDs. ARWS values close to 1 mean that irrigation and rainfall have been used efficiently to cover ET. Values from 0.9 to 1.2 indicate the ID follows a proper irrigation management as it was shown in other irrigation districts in the region by Naroua et al. (2014). CVG used more efficiently the precipitation water to fulfil the corn needs but this was not observed in the remainder IDs, which depended more on irrigation than precipitation. Consequently, precipitation should be used more efficiently by IDs, especially SGVT and VC.

The upper limit is exceeded in VC (2014, 2015 and 2017) and in SGVT (2014, 2015 and 2016). Only in CTZ, it is below the lower limit (2017). The SGVT district showed the highest temporal variability, and CVG the lowest. These results highlight a proper irrigation management for corn in the IDs as it was shown by other authors in South Spain (Moreno-Pérez and Roldán-Cañas, 2013) and in the central Spain (Naroua et al., 2014).

The RRS (Eq. (6)) indicates the contribution of the effective precipitation to the crop water requirements. Both the temporal variability (within an irrigation district) and the spatial variability (among irrigation districts) were high, with RRS values ranging from 0.02 (SGVT, 2014 and CVG, 2016) and 0.12 (CTZ, 2017). These values were lower than the ones reported by Naroua et al. (2014) for an ID in central Spain. Overall, rainfall only supplies less than $10 \%$ of corn water requirements, consequently irrigation will be required to fulfil them in all 


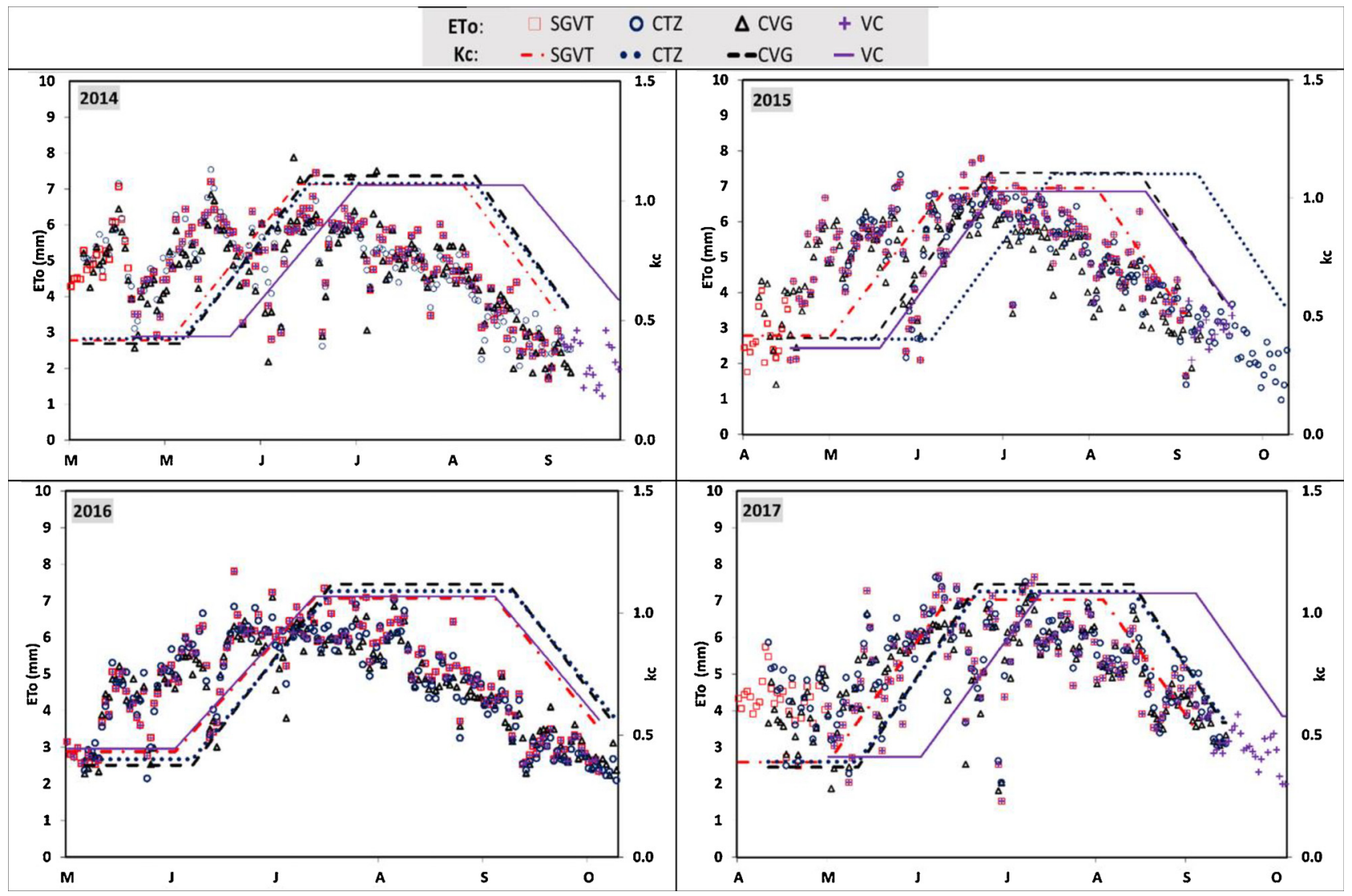

Fig. 5. Temporal evolution of ETo and the Kc fitted curves for the growing season in the Irrigation Districts.

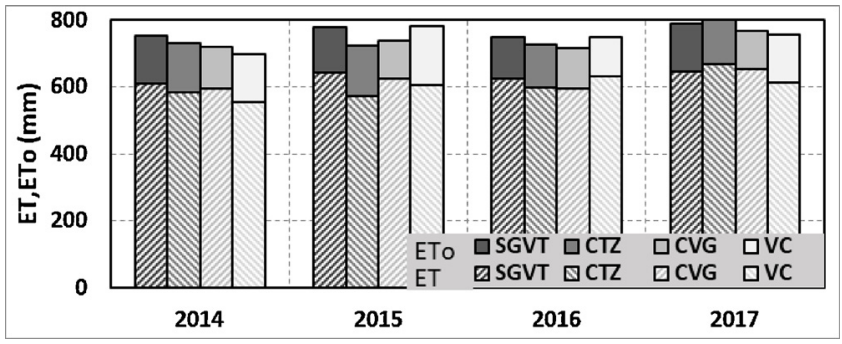

Fig. 6. Temporal evolution of ET and ETo during the corn growing period.

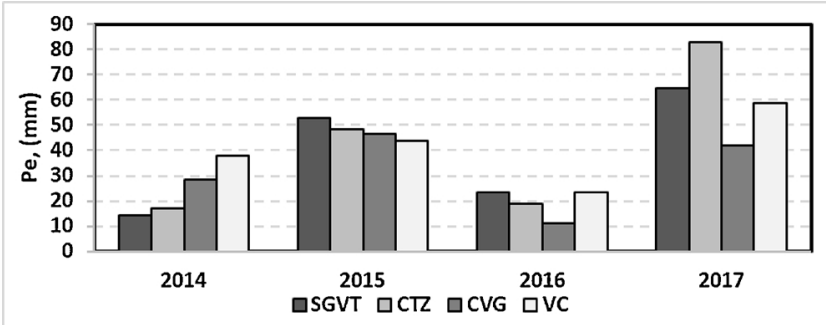

Fig. 7. Cumulate precipitation for the corn growth season and the study period.

IDs.

\section{Conclusions}

Corn is a high water requirement crop and most of its needs are fulfil by irrigation in the assessed irrigation districts. For the study period (2014-2017), the water use efficiency indicators varied among the irrigation districts across the Duero river basin. They depended upon the hydrologic year, the water available for irrigation (superficial and subsurface water), and the corn sowing date. Usually, the irrigation districts performed deficit irrigation (ARIS $<1$ ) in the dry years and either full irrigation (ARIS $=1$ ) or over irrigation (ARIS $>1$ ) in the wet years.

ARWS values ranged from 0.77 to 1.47 and rainfall only fulfilled up to $10 \%$ of corn requirements. In most IDs, these values were higher than 1 indicating a poor efficiency use from the precipitation water, especially in SGVT and VC where the corn water requirements were covered by irrigation. On the contrary, CVG was the irrigation district with the best ARWS, and it was not only able to use irrigation water to fulfil the corn water needs, but also made and efficient used of rain water.

The satellite images and the methodology proposed are adequate to estimate the local corn Kc coefficients and its irrigation requirements, in the irrigation districts from the Spanish Duero basin. For the study period, the differences in corn coefficient were negligible within municipalities (for each irrigation district), and they also were small among irrigation districts. The corn coefficient fitted curves showed a good correlation with the estimated data and their pattern varied among districts affected by differences in sowing dates.

The estimated local corn coefficients $\left(\mathrm{Kc}_{\mathrm{ini}}=0.41 \pm 0.01\right.$, $\mathrm{Kc}_{\text {mid }}=1.08 \pm 0.01$ and $\mathrm{Kc}_{\text {end }}=0.55 \pm 0.01$ ), slightly differed from the general coefficients recommended by the Irrigation Advisory Services (ITACyL, $\mathrm{Kc}_{\text {ini }}=0.45, \mathrm{Kc}_{\text {mid }}=1.1$ and $\mathrm{Kc}_{\text {end }}=0.5$ ). However, they affected the determination of the gross irrigation requirements: the $\mathrm{Kc}_{\text {ITACyL }}$ underestimates crop water requirements. Likewise, the crop growth stages' length was different, although the one estimated in this study was similar to the FAO recommendations.

The gross irrigation requirements were similar among irrigation districts and years, varying between 6988 and $7362 \mathrm{~m}^{3} / \mathrm{ha}$. Although they were covered in most of the years and IDs, the water availability did not fulfil corn water requirements and farmers applied deficit 
Table 8

Temporal evolution of the gross irrigation requirements calculated with the corn coefficients: $\mathrm{Kc}_{\text {satellite }}$ and $\mathrm{Kc}_{\mathrm{ITACyL}}$.

\begin{tabular}{|c|c|c|c|c|c|c|c|c|c|c|c|c|}
\hline \multirow[t]{2}{*}{ Year } & \multicolumn{6}{|c|}{$\begin{array}{l}\text { GIR } \\
\left(\mathrm{m}^{3} / \mathrm{ha}\right)\end{array}$} & \multicolumn{6}{|c|}{$\begin{array}{l}\text { GIR (ITACyL) } \\
\left(\mathrm{m}^{3} / \mathrm{ha}\right)\end{array}$} \\
\hline & SGVT & CTZ & CVG & VC & Mean & $\mathrm{CV}$ & SGVT & CTZ & CVG & VC & Mean & CV \\
\hline 2014 & 7379 & 7043 & 7053 & 6476 & 6988 & 0.05 & 6850 & 6489 & 6402 & 5900 & 6410 & 0.06 \\
\hline 2015 & 7379 & 6579 & 7200 & 7030 & 7047 & 0.05 & 7001 & 5882 & 6457 & 6854 & 6549 & 0.08 \\
\hline 2016 & 7464 & 7196 & 7232 & 7557 & 7362 & 0.02 & 6869 & 6538 & 6539 & 6869 & 6704 & 0.03 \\
\hline 2017 & 7325 & 7397 & 7646 & 6974 & 7335 & 0.04 & 6896 & 6725 & 6893 & 6353 & 6717 & 0.04 \\
\hline Mean & 7387 & 7054 & 7283 & 7009 & 7183 & 0.03 & 6904 & 6408 & 6573 & 6494 & 6595 & 0.03 \\
\hline CV & 0.01 & 0.05 & 0.03 & 0.06 & 0.03 & & 0.01 & 0.06 & 0.03 & 0.07 & 0.02 & \\
\hline
\end{tabular}

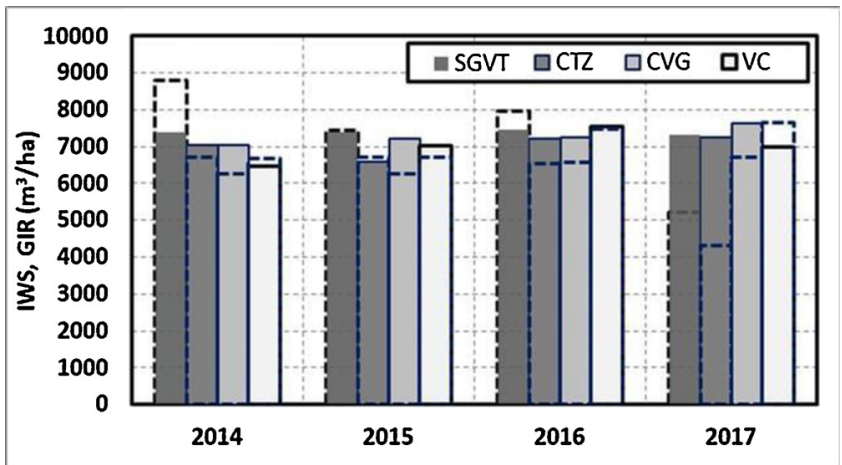

Fig. 8. Comparison of gross irrigation requirements (GIR) and the actual irrigation supply (IWS).

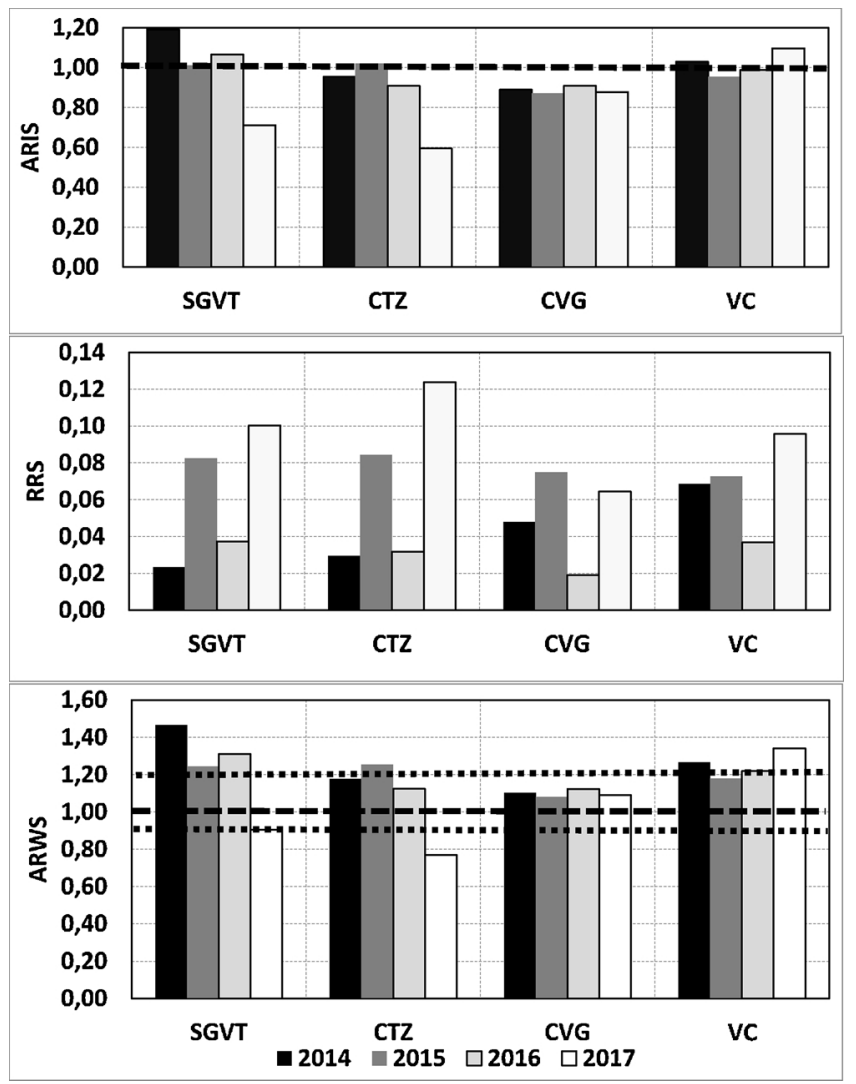

Fig. 9. Corn water use efficiency indicators in the irrigation districts during the study period: (a) ARIS, (b), ARWS and (c) RRS. irrigation. Only in the VC irrigation district, the available water was higher than the crop demand because it pumped subsurface water during the dry season. It is noted that from an economic point of view, this irrigation district might be less efficient than the others since it would have to consider the cost of energy, among others factors.

The actual irrigation supply, for each irrigation district, depended on the water storage in the irrigation reservoirs, which also depends on the hydrological year. In this study, 2016 was the driest year but IWS performed properly because of the water storage in 2015. However, 2017 was drier than 2016 having an effect on the water storage and producing a deficit in IWS.

The local Kc coefficient estimated for the region and the irrigation efficiency assessment are based on criteria to satisfy the crop evapotranspiration requirements, and not considered the cost-benefit ratio. Therefore, the window is still open for future research to adjust the irrigation doses with deficit irrigation criteria, taking into account water cost and crop yields, resulting in a better cost-benefit ratio which favors both the producers' income and environment.

\section{Suggestions}

In the irrigation districts located in the Spanish Duero river basin, the corn water requirements are calculated with the general crop Kc coefficients recommended by the Regional Advisory Services (ITACyL). These have not been yet adapted to local conditions resulting in a GIR underestimation. However for each irrigation season, it is advisable to estimate local corn coefficient by using the open satellite dataset form the SPIDERWEBGIS and the methodology proposed in this paper. Local corn coefficients would feature better the characteristics for each irrigation district and moreover, the gross irrigation requirements would be properly addressed. Likewise, it is also proposed to consider as the corn growth stages length, the FAO recommendation instead of ITACyL, since the first fitted better the local corn coefficients. Nevertheless, this length could be modified in further research.

In general, the irrigation supply is adequate for most irrigation districts although some of them applied over irrigation and did not use efficiently the rain water. This could be avoided if local corn coefficients were determined.

\section{Acknowledgments}

The authors wish to thank to the technical managers from the irrigation districts (Canal Simancas, Geria and Villamarciel of Tordesillas; Canal Villagonzalo; Canal Toro Zamora and Villalar of Comuneros) they support for this study. Without their information, the work would have not been addressed.

Likewise, the authors wish to thank to the Instituto Técnico Agronómico Provincial de Albacete (ITAP) for its help in the use of the SPIDERWEBGIS software and to SIAR- MAPAMA for the data. 


\section{References}

Allen, R.G., Pereira, L.S., Raes, D., Smith, M., 1998. Crop Evapotranspiration. Guidelines for Computing Crop Requirements. Irrigation and Drainage Paper No. 56. Food and Agriculture Organization, Rome.

Allen, R.G., Pereira, L.S., Howell, T.A., Jensen, M.E., 2011. Evapotranspiration information reporting: I. factors governing measurement accuracy. Agric. Water Manage. 98 (6), 899-920.

Andrés, R., Cuchí, J.A., 2014. Analysis of sprinkler irrigation management in the LASESA district, Monegros (Spain). Agric. Water Manage. 131, 95-107.

Battude, M., Al Bitar, A., Brut, A., Tallec, T., Huc, M., Cros, J., Weber, J.J., Lhuissier, L., Simonneaux, V., Demarez, V., 2017. Modeling water needs and total irrigation depths of corn crop in the south west of France using high spatial and temporal resolution satellite imagery. Agric. Water Manage 189, 123-136.

Bausch, W.C., 1993. Soil background effects on reflectance-based crop coefficients for corn. Remote Sens. Environ. 46, 213-222.

Bausch, W.C., Neale, C.M.U., 1987. Crop coefficients derived from reflected canopy radiation-a concept. Trans. ASAE 30, 703-709.

Bos, M.G., 1997. Performance indicators for irrigation and drainage. Irrig. Drain. Syst. Eng. 11, 119-137.

Calera, A., González-Piqueras, J., Melia, J., 2004. Monitoring barley and corn growth from remote sensing data at field scale. Int. J. Remote Sens. 25, 97-109.

Calera, A., Jochum, A.M., Cuesta-Garcia, A., Montoro-Rodriguez, A., Lopez-Fuster, P., 2005. Irrigation management from space: towards user-friendly products. Irrig. Drain. Syst. 19, 337-353.

Calera, A., Campos, I., Osann, A., D’Urso, G., Menenti, M., 2017. Remote sensing for crop water management: from ET modelling to services for the end users. Sensors 17.

Campos, I., Neale, C.M.U., Calera, A., Balbontin, C., González-Piqueras, J., 2010. Assesing satellite-based basal crop coefficients for irrigated grapes (Vitis vinifera L.). Agric. Water Manage. 98, 45-54.

Casa, R., Rossi, M., Sappa, G., Trotta, A., 2009. Assessing crop water demand by remote sensing and GIS for the pontina plain, Central Italy. Water Resour. Manage. 23 (9), 1685-1712.

Clemmens, A.J., Molden, D.J., 2007. Water uses and productivity of irrigation systems. Irrig. Sci. 25, 247-261.

Consoli, S., Barbagallo, A., 2012. Estimating water requirements of an irrigated mediterranean vineyard using a satellite-based approach. J. Irrig. Drain. E-ASCE 138 (10).

Cuesta, A., Montoro, A., Jochum, A.M., López, P., Calera, A., 2005. Metodología operativa para la obtención del coeficiente de cultivo desde imágenes de satélite. ITEAInformación Técnica Económica Agraria 101 (3), 212-224.

Droogers, P., Kite, G., 1999. Water productivity from integrated basin modeling. Irrig. Drain. Syst. 13, 275-290.

Droogers, P., Kite, G., Murray-Rust, H., 2000. Use of simulation models to evaluate irrigation performance including water productivity, risk and system analyses. Irrig. Sci. 19, 139-145.

FAO, 2017. The Future of Food and Agriculture: Trends and Challenges. Food and Agriculture Organization of the United Nations Publications, Rome.

Glenn, E.P., Huete, A.R., Nagler, P.Ol., Nelson, S.G., 2008. Relationship between remotely-sensed vegetation indices, canopy attributes and plant physiological processes: what vegetation indices can and cannot tell us about the landscape. Sensors 8, 2136-2160.

Glenn, E.P., Neale, C.M.U., Hunsaker, D.J., Nagler, P.L., 2011. Vegetation index-based crop coefficients to estimate evapotranspiration by remote sensing in agricultural and natural ecosystems. Hydrol. Processes 25, 4050-4062.

Gontia, N.K., Tiwari, K.N., 2010. Estimation of crop coefficient and evapotranspiration of wheat (Triticum aestivum) in an irrigation command using remote sensing and GIS. Water Resour. Manage. 4 (7), 1399-1414.

Gonzalez-Dugo, M.P., Neale, C.M.U., Mateos, L., Kustas, W.P., Prueger, J.H., Anderson, M.C., Li, F., 2009. A comparison of operational remote sensing-based models for estimating crop evapotranspiration. Agric. For. Meteorol. 149, 1843-1853.

Guerra, E., Ventura, F., Snyder, R.L., 2016. Crop coefficients: a literature review. J. Irrig. Drain. E-ASCE 142 (3).

ITACyL, 2012. Plan De Monitorización Del Regadío En Castilla y León (Available "on line”. Resultados del Seguimiento de Cultivos de la Campaña 2011 ) (Accessed January 2018). http://www.inforiego.org.

ITACyL, 2017. Suelos Castilla y Leon. (Accessed July 2018). http://suelos.itacyl.es/ visor_datos.
Kassam, A.H., Molden, D., Fereres, E., Doorenbos, J., 2007. Water productivity: science and practice-Introduction. Irrig. Sci. 25, 185-188.

Lorite, I.J., Mateos, L., Fereres, E., 2004a. Evaluating irrigation performance in a Mediterranean environment. I. model and general assessment of an irrigation scheme. Irrig. Sci. 23, 77-84.

Lorite, I.J., Mateos, L., Fereres, E., 2004b. Evaluating irrigation performance in a Mediterranean environment. II. variability among crops and farmers. Irrig. Sci. 23, 85-92.

Lu, Y., Xu, J., Yang, S., Liu, X., Zhang, J., Wang, Y., 2017. Inter-seasonal and crosstreatment variability in single-crop coefficients for rice evapotranspiration estimation and their validation under drying-wetting cycle conditions. Agric. Water Manage. 196, 154-161.

Marques, G.F., Lund, J.R., Howitt, R.E., 2005. Modeling irrigated agricultural production and water use decisions under water supply uncertainty. Water Resour. 41 (8).

Melton, F.S., Johnson, L.F., Lund, C.P., Pierce, L.L., Michaelis, A.R., Hiatt, S.H., Guzman, A., Adhikari, D.D., Purdy, A.J., Rosevelt, C., Votava, P., Trout, T.J., Temesgen, B., Frame, K., Sheffner, E.J., Nemani, R.R., 2012. Satellite irrigation management support with the terrestrial observation and prediction system: a framework for integration of satellite and surface observations to support improvements in agricultural water resource management. IEEE J. Sel. Top. Appl. Earth Obs. Remote Sens. 5, 1709-1721.

Moreno-Pérez, M.F., Roldán-Cañas, J., 2013. Assessment of irrigation water management in the Genil-Cabra (Córdoba, Spain) irrigation district using irrigation indicators. Agric. Water Manage. 120, 98-106.

Nafría, D.A., Garrido, N., Álvarez, M.V., Cubero, D., Fernández, M., Villarino, I., Gutiérrez, A., Abia, I., 2013. Atlas Agroclimático Castilla y León (Available "on line". AEMET-ITACyL, Valladolid ). (Accessed January 2018). http://atlas.ITACyL.es.

Naroua, I., Rodríguez-Sinobas, L., Sánchez-Calvo, R., Rodríguez-Ros, J., 2012. Evaluación de los Sistemas de Riego por Aspersión en la Comunidad de Regantes "Río Adaja" y propuestas para la mejora del manejo del riego. XXX Congreso Nacional de Riegos AERYD.

Naroua, I., Rodríguez-Sinobas, L., Sánchez Calvo, R., 2014. Water use efficiency and water productivity in the Spanish irrigation district "Río Adaja". Int. J. Agric. Policy Res. 2 (12), 484-491.

Neale, C., Bausch, W., Heerman, D., 1989. Development of reflectance-based crop coefficients for corn. Trans. ASAE 32, 1891-1899.

Pôças, I., Paço, T.A., Paredes, P., Cunha, M., Pereira, L.S., 2015. Estimation of actual crop coefficients using remotely sensed vegetation indices and soil water balance modelled data. Remote Sens. 7, 2373-2400.

Roerink, G.J., Bastiaanssen, W.G.M., Chambouleyron, J., Menenti, M., 1997. Relating crop water consumption to irrigation water supply by remote sensing. Water Resour. Manage. 11, 445-465.

Salvador, R., Martinez-Cob, A., Cavero, J., Playán, E., 2011. Seasonal on-farm irrigation performance in the Ebro Basin (Spain): crops and irrigation systems. Agric. Water Manage. 98 (4), 577-587.

Sun, H.Y., Liu, C.M., Zhang, X.Y., Shen, Y.J., Zhang, Y.Q., 2006. Effects of irrigation on water balance, yield and WUE of winter wheat in the North China Plain. Agric. Water Manage. 85 (1-2), 211-218.

Toureiro, C., Serralheiro, R., Shahidian, S., Sousa, A., 2017. Irrigation management with remote sensing: evaluating irrigation requirement for maize under Mediterranean climate condition. Agric. Water Manage. 184, 211-220.

Tucker, C.J., Elgin, H.J., McMurtrey, J.E.I., Fran, C.J., 1979. Monitoring corn and soybean crop development with hand-held radiometer spectral data. Remote Sens. Environ. 8, 237-248.

Vanino, S., Pulighe, G., Nino, P., De Michele, C., Bolognesi, S.F., D’Urso, G., 2015 Estimation of evapotranspiration and crop coefficients of tendone vineyards using multi-sensor remote sensing data in a mediterranean environment. Remote Sens. (Basel) 7, 14708-14730.

Vazifedoust, M., Van Dam, J.C., Feddes, R.A., Feizi, M., 2008. Increasing water productivity of irrigated crops under limited water supply at field scale. Agric. Water Manage. 95 (2), 89-102.

Villalobos, F.J., Fereres, E., 2002. Fitotecnia. Bases y Tecnologías de la Producción Agrícola. Ed.. MundiPrensa, Madrid.

Zohrab Samani, Z., Salim, A., Bleiweiss, B.M., Skaggs, R., Longworth, J., Tran, V.D., Pinon, A., 2009. Using remote sensing to evaluate the spatial variability of evapotranspiration and crop coefficient in the lower Rio Grande Valley, New Mexico. Irrig Sci. 28. 